\title{
Huia caspica gen. \& comb. nov., a dinoflagellate species that recently crossed the marine-freshwater boundary
}

\author{
Gu Haifeng ${ }^{1,{ }^{*}}$, Mertens Kenneth ${ }^{2}$, Liu Tingting ${ }^{1}$ \\ ${ }^{1}$ Third Inst Oceanog, Dept Marine Biol \& Ecol, Xiamen, Peoples R China. \\ 2 IFREMER, LER BO, Stn Biol Marine, Concarneau, France. \\ *Corresponding author : Haigeng Gu, email address : guhaifeng@tio.org.cn
}

\begin{abstract}
:
The dinoflagellate subfamily Diplopsalidoideae encompasses 11 genera whose plate patterns show a large diversity. In a recently published molecular phylogeny (Liu et al. 2015) some of these genera (e.g. Diplopsalis, Diplopelta) are polyphyletic, suggesting that further subdivision of these genera is needed. Here we established the cyst-theca relationship of Diplopsalis caspica by incubating cysts collected from the East China Sea. Cells of $D$. caspica display a plate formula of Po, X, 3', 1a, 6", 3c+t, ?4s, 5"', $1^{\prime \prime \prime}$, characterized by a small, parallelogrammic anterior intercalary plate (1a) located in the middle of the dorsal part of the epitheca. The cysts are spherical and smooth-walled with a theropylic archeopyle. In addition, we obtained four large subunit ribosomal DNA (LSU rDNA) sequences from the germinated motile cells by single-cell polymerase chain reaction. Strains of $D$. caspica from the marine environment of the East China Sea differ at 0-2 positions of LSU rDNA sequences from that of lacustrine strains from NE China. In the molecular phylogeny, D. caspica was close to Lebouraia pusilla but distant from $D$. lenticula, the type species of Diplopsalis. Our results support the systematic importance of plate 1a, and therefore $D$. caspica was transferred to a new genus, Huia. The conservative LSU rDNA sequences in $H$. caspica suggest that the marine-freshwater transition occurred recently.
\end{abstract}

Keywords : cyst-theca relationship, diplopsalioideans, Diplopsalis caspica, Glenodinium caspica, LSU rDNA 


\section{INTRODUCTION}

The dinoflagellate subfamily Diplopsalidoideae Abé, informally called the diplopsalioideans, includes 11 genera, characterized by four or five climactal plates, one antapical (fundital) plate or either of these features (Matsuoka 1988; Fensome et al. 1993). The type genus of this subfamily, Diplopsalis Bergh, was characterized by the plate pattern of Po, X, 3', 1a, 6", 3c+t, 5s?, 5"', 1"'" (Bergh \& Daday 1881; Nie 1943). Other genera (e.g. Boreadinium J. D. Dodge \& H. B. Hermes, Diplopelta Stein, Diplopsalopsis Meunier, Oblea Balech ex Loeblich Jr. \& Loeblich III, Preperidinium Mangin) differ from Diplopsalis only in the number of anterior intercalary or precingular /antapical plates (Abé 1941; Abé 1981; Dodge \& Hermes 1981; Dodge \& Toriumi 1993).

Diplopsalis caspica was originally described by Ostenfeld (1902) as possessing three apical plates, and five - what he called - "praemedian" plates, which corresponds to four precingular plates and a small diamond shaped anterior intercalary plate. Later, Ostenfeld (1908) re-observed this species from the Aral Sea, did not comment on his previous description, but redrew the species as having six precingular plates, sharing an identical plate pattern with D. lenticula. Lemmermann (1910, p. 674) considered it to belong to the genus Peridinium Ehrenberg, and transferred it to Peridinium caspicum (Ostenfeld) Lemmermann. Lindemann (1927, p. 419-420) restudied samples from the Caspian Sea and did not agree with Lemmermann's reassignment of the species and considered Ostenfeld's specimen published in 1908 a typical Diplopsalis; his own specimens however showed variation in the shape of second 
intercalary plate (being quadra or penta) and number of precingular plates. It is doubtful whether these correspond to the same species. Schiller (1935, p. 110) however, considered it to belong to the genus Glenodinium Ehrenberg, and named it Glenodinium caspicum (Ostenfeld) Schiller. The species has not been reported subsequently although it is easily recognized by the small, diamond shaped anterior intercalary plate. In 2015 it was again reported from Jihongtan reservoir at Qingdao, Shandong Province, China, and its detailed morphology was documented for the first time (Zhang et al. 2015). Zhang et al. (2015) provided a complete tabulation of Po, X, $3^{\prime}, 1 \mathrm{a}, 6^{\prime \prime}, 4 \mathrm{c}, 4 \mathrm{~s}, 5^{\prime \prime \prime}, 1^{\prime \prime \prime \prime}$. This tabulation and the phylogenetic position reported by Zhang et al. (2015) suggested a warranted attribution of this species to the genus Diplopsalis.

Another molecular phylogeny published later, based on large subunit ribosomal DNA (LSU rDNA) sequences largely supported the validity of the diplopsalid genera, but two new genera (Niea T. Liu, K.N. Mertens \& H. Gu and Qia T. Liu, K.N. Mertens \& H. Gu) were established based on the shape of the first apical plate or the anterior intercalary plate, although they share an identical plate pattern with Oblea and Diplopsalis (Liu et al. 2015). As a consequence, the genera Diplopsalis and Oblea were emended by Liu et al. (2015). However, Diplopsalis caspica did not fit this emended description, and in the molecular phylogeny reported by Liu et al. (2015) the genus Diplopsalis is polyphyletic, suggesting that nomenclatural changes are needed. These systematic changes are suggested here. 
A cyst stage has not been reported for Diplopsalis caspica, although cyst stages are commonly found in the diplopsalioideans. In contrast with the closely related Protoperidinium species, the cyst morphology of diplopsalioideans is rather conservative. The latter are generally spherical and smooth with a theropylic archeopyle, corresponding to suturing along predetermined plate boundaries (Matsuoka 1988; Lewis 1990; Dale et al. 1993). Only three species, Niea acanthocysta (Kawami, Iwataki \& Matsuoka) T. Liu, K.N. Mertens \& H. Gu, Niea chinensis T. Liu, K.N. Mertens \& H. Gu and Diplopelta symmetrica Pavillard, produce cysts with processes (Dale et al. 1993; Kawami et al. 2006; Liu et al. 2015), which is helpful to differentiate species with similar thecate morphology. Here the cyst-theca relationship of Diplopsalis caspica is established for the first time.

In terms of ecological preferences $D$. caspica has previously been reported from brackish waters by Ostenfeld $(1902,1908)$ and from fresh water by Zhang et al. (2015). There are approximately 1,700 extant marine species and 220 freshwater species of dinoflagellates (Taylor et al. 2008). The first marine dinoflagellates are suggested to have originated around 250 million years ago based on the fossil record (Fensome et al. 1996), however, only a fraction of dinoflagellates have succeeded in colonizing fresh water habitat (Logares et al. 2007b). The earliest colonization extended back to 150 million years ago, based on the fossil cyst record produced by freshwater dinoflagellates (Batten 1989). More recent invasions were reported for the lacustrine species "Peridinium" aciculiferum, which occurred around 30 million years ago (Logares et al. 2007b). Historical colonization inevitably led to ecological 
speciation, but species splitting might have not finished yet, such as Kolkwitziella acuta (Apstein) Elbrächter and Diplopsalis caspica, two species inhabiting brackish as well as fresh water (Ostenfeld 1902; Mertens et al. 2015; Zhang et al. 2015). Here we report the presence of $D$. caspica from fully marine waters for the first time, report its cyst-theca relationship and phylogenetic position using a newly obtained LSU rDNA sequence, and explore when the marine-freshwater transition occurred.

\section{MATERIALS AND METHODS}

Surface sediment samples were collected with a small boat using a Van Veen grab nearby Fuzhou (East China Sea, $25.8275^{\circ} \mathrm{N}, 119.7307^{\circ} \mathrm{E}$, salinity $=28$ ) on November 28, 2010 (Fig. S1). All samples were stored in the dark at $4^{\circ} \mathrm{C}$ until further treatment. Approximately $5 \mathrm{~g}$ wet weight of sediment material was diluted in a $20 \mathrm{~mL}$ beaker with filtered seawater with a salinity of 30 and sonicated for $1 \mathrm{~min}$ in an ultrasonic bath (JY96 Xinzhi, Ningbo, China). The water slurry was rinsed with filtered seawater whilst sieving through a $20 \mu \mathrm{m}$ nylon mesh. The fraction retained by the sieve was resuspended with $1 \mathrm{~mL}$ filtered seawater, and used for cyst isolation. Using a BX51 microscope (Olympus Corp., Tokyo, Japan), nine spherical and brown cysts were isolated with a micropipette into 96 well plates, with each well containing 300 $\mu \mathrm{L} \mathrm{f} / 2$-Si medium (Guillard \& Ryther 1962). The plates were incubated at $20^{\circ} \mathrm{C}, 90$ $\mu \mathrm{mol}$ photons $\cdot \mathrm{m}^{-2} \cdot \mathrm{s}^{-1}$ with a light: dark cycle of $12: 12 \mathrm{~h}$, and examined daily with an inverted microscope AE31 (Motic, Xiamen, China).

After germination, both cells and empty cysts were individually transferred onto cleaned glass slides and examined at $\times 400$ magnification with the light microscope 
with a digital camera (Qimaging, Burnaby, Canada). No mounting medium was used. Calcofluor white was used to discern plates in vegetative cells (Fritz \& Triemer 1985). The Kofoidian system was used for designating the thecal plates (Fensome et al. 1993). All cyst and motile cell measurements in the species descriptions cite the minimum, average (in parentheses) and maximum values, in that order.

Identified cells were rinsed several times in sterilized distilled water, broken by squeezing the coverslip above, and then transferred into a PCR tube. Four germinated cells were used as the template to amplify about $1430 \mathrm{bp}$ of the LSU rRNA gene (D1-D6 domains), using the primers D1R (forward, 5'-ACCCGCTGAATTTAAGCATA-3') (Scholin et al. 1994) and 28-1483R (reverse, 5'-GCTACTACCACCAAGATCTGC-3') (Daugbjerg et al. 2000). A $50 \mu \mathrm{L}$ PCR cocktail containing $0.2 \mu \mathrm{M}$ forward and reverse primer, PCR buffer, $50 \mu \mathrm{M}$ dNTP, 1U of Taq DNA polymerase (Takara, Dalian, China) was subjected to 35 cycles using a Mastercycler PCR (Eppendorf, Hamburg, Germany). The PCR protocol was identical to that of Liu et al. (2015). Sequences were deposited in GenBank (KX056274 - KX056276).

Sequences newly obtained were first aligned with those of related species available in GenBank using BioEdit v7.0.0 (Hall 1999) and Mafft (Katoh et al. 2005). The apicomplexan Neospora caninum Dubey, Carpenter, Speer, Topper \& Ugglawas selected as an outgroup. A general time reversible model $(\mathrm{GTR}+\mathrm{G})$ was selected with Akaike information criterion based on the result of JmodelTest (Posada 2008). Maximum likelihood (ML) analyses were conducted with „RAxML ${ }^{c e}$ v7.2.6 
(Stamatakis 2006) using the best-fitting substitution model on the T-REX web server (Boc et al. 2012). Bootstrap analysis was based on 1000 replicates. A Bayesian inference (BI) analysis was performed with MrBayes 3.0b4 (Ronquist \& Huelsenbeck 2003) using the best-fitting substitution model. Four Markov chain Monte Carlo chains ran for ten million generations, sampling every 1000 generations with a burnin of $10 \%$. A majority rule consensus tree was created in order to examine the posterior probabilities of each clade.

\section{RESULTS}

Huia H. Gu, K.N. Mertens, T. Liu gen. nov.

Description. Armoured dinoflagellate with a plate formula of Po, X, 3', 1a, 6", $3 \mathrm{c}+\mathrm{t}, ? 4 \mathrm{~s}, 5^{\prime \prime \prime}, 1$ "'". A small, parallelogrammic anterior intercalary plate (1a) located in the middle of the dorsal part of the epitheca. Cysts spherical and smooth, with a theropylic archeopyle.

Type species: Huia caspica (Ostenfeld) H. Gu, K.N. Mertens, T. Liu comb. nov.

Basionym: Diplopsalis caspica Ostenfeld (1902, Phytoplankton fra det Kaspiske Hav. Videnskabelige Meddelelser fra Dansk Naturhistorisk Forening 1901: pp. 132, 133, fig. 1).

Synonyms: Peridinium caspicum (Ostenfeld) Lemmermann 1910, p. 674, figs 1-5; Glenodinium caspicum (Ostenfeld) Schiller 1935, p. 110, fig. 105a-d.

Etymology: the genus is named in honor of professor Hongjun $\mathrm{Hu}$ who has carried out pioneering taxonomic work on freshwater microalgae in China.

A total of six cysts germinated which yielded motile cells after between one to 
seven days of incubation. The vegetative cells are subspherical, contain lipid bodies and are pale green in color (Fig. 1). The plate formula is Po, X, 3', 1a, 6", 3c+t,?4s, 5'", $1^{\prime \prime \prime \prime}$. The first apical plate $\left(1^{\prime}\right)$ is rhombic (ortho-type), in touch with the canal plate and anterior part of the anterior sulcal plate (Sa) (Figs 2,4). The apical pore complex consists of a round pore plate $(\mathrm{Po})$ raising to form a pronounced horn and a short canal plate (X) (Fig.3). Plates $2^{\prime}$ and $3^{\prime}$ are six-sided with the latter relatively larger (Fig. 5). There is only one small, parallelogrammic anterior intercalary plate (1a) located in the middle of the dorsal part of the epitheca (Fig. 5). Among the six precingular plates, plates $3^{\prime \prime}, 4^{\prime \prime}$ and $6 "$ are five-sided whereas the others are four-sided (Fig. 5). The cingulum consists of three cingular plates plus a transitional plate and descends slightly with a displacement less than half of its width (Figs 2, 4, 6). The cingulum has short cingular list with ribs (Figs 2, 4). We were unable to verify the exact number of sulcal plates, but it comprises at least a Sa plate, a left sulcal plate (Ss), a right sulcal plate (Sd) and a posterior plate (Sp) (Figs 2, 7). The cells have a C type of anterior sulcal (Sa) plate sensu Dodge \& Hermes (1981). The left sulcal plate (Ss) is sheltered by a large list on the left of the sulcus (Fig. 2); The posterior sulcus plate ( $\mathrm{Sp}$ ) is small and of the Caspica-type (Fig. 7). The five postcingular plates are four-sided and there is only one large antapical plate (Fig. 7). The thecal plates are ornamented with numerous pores, which are often arranged in rows in marginal areas (Figs 5,7$)$. The living cyst is spherical and brown, full of pale granules and has a thick wall (Fig. 8). The surface of the cyst wall is smooth and devoid of ornamentation (Fig. 9). The archeopyle is theropylic, following the sutures between 
plates 2', 1a, 3' and 2", 3", 4", 5" (Figs 10-12).

The incubated motile cells are 30.0 (35.8) $38.0 \mu \mathrm{m}$ long and 32.0 (38.2) $40.0 \mu \mathrm{m}$ wide $(n=6)$, and the cysts germinated to give identifiable thecae are 35.0 (39.7) 43.0 $\mu \mathrm{m}$ in diameter $(\mathrm{n}=6)$.

Molecular phylogenetics

Four cells of Huia caspica from the East China Sea share nearly identical LSU rDNA sequences, differing only in 1 or 2 positions. One of these sequences is identical to that of Diplopsalis caspica (KJ995959) isolated from freshwater (Zhang et al. 2015).

The best phylogenetic tree constructed by BI analyses (Fig. 13) was similar to the ML tree differing only in a few internal nodes, such as the Peridinium cinctum (O. F. Müller) Ehrenberg and Akashiwo sanguinea (K. Hirasaka) G. Hansen \& Ø. Moestrup groups. The subfamily Diplopsalidoideae was polyphyletic and consisted of three well-resolved clades (I, II, III) intermingled by clades Protoperidinium sensu stricto, Oceanica and Monovela. Huia caspica and Lebouraia pusilla (Balech \& R.Akselman) J. D. Dodge \& S. Toriumi form a clade with strong support (ML bootstrap: 100/ BI posterior probability: 0.95). They were nested within clade Diplopsalidoideae I together with Diplopsalis lenticula Bergh, Oblea rotunda and Boreadinium breve (Abé) Sournia.

\section{DISCUSSION}

Here we present evidence that $H$. caspica can inhabit fully marine environments for the first time. The marine cells of $H$. caspica $(32-40 \mu \mathrm{m})$ are more slender than those 
from brackish $(56-72 \mu \mathrm{m})$ and fresh water $(48-60 \mu \mathrm{m})$ (Ostenfeld 1902; Zhang et al. 2015). We consider them conspecific since the size of cells can be variable in many species (e.g. Mertens et al. 2015).

Like other diplopsalioideans, Huia caspica has a complex taxonomic history. It has been transferred to Peridinium (Lemmermann 1910) and Glenodinium (Schiller 1935). Huia caspica does not belong to the genus Peridinium, since this is now considered to be characterized by five cingular plates, as observed on the type species, Peridinium cinctum (Boltovskoy 1975), which contrasts with four cingular plates $(3 \mathrm{c}+\mathrm{t})$ in $H$. caspica. The attribution to the genus Glenodinium is difficult to assess, since the genus Glenodinium has been too vaguely described by Ehrenberg (1836) (see e.g. Loeblich 1980). The plates of its type species G. cinctum Ehrenberg were not described, but it possesses plastids and a red horseshoe-shaped eyespot (Ehrenberg 1836). Several Glenodinium species have been reclassified, for instance, $G$. ambiguum Thompson and G. balticum Levander were transferred to Kansodinium Carty et Cox and Durinskia Carty et Cox respectively (Carty \& Cox 1986), and more recently, G. edax was transferred to Tyrrannodinium (Calado 2011) and G. acuminatum (Ehrenb.) E. Jørgensen was transferred to Scrippsiella (Kretschmann et al. 2015). Wołoszyńska (1917) even transferred G. cinctum (the type species of Glenodinium) to Sphaerodinium (characterized by a plate pattern of 4', 4a, 7", ?c, ?s, 6"', 2"'" by Wołoszyńska 1917; four sulcal plates and possibly eight cingular plates in Sphaerodinium cracoviense as observed by Craveiro et al. 2010) because both genera have a distinctive horseshoe shaped eyespot, but if that was true, Sphaerodinium 
became a junior synonym of Glenodinium (Loeblich 1980). Either way, it is unlikely that D. caspica would belong to Glenodinium.

Very recently, the genus Diplopsalis has been emended to incorporate only those species with a narrow, five-sided anterior intercalary plate located in the lower part of the dorsal epitheca (Liu et al. 2015). As a consequence, D. lebouriae was transferred to a new genus Qia because it possesses a six-sided anterior intercalary plate. In this emended description, Diplopsalis is not suitable to incorporate D. caspica because of its small anterior intercalary plate, thus we transfer it to a new genus Huia.

Kansodinium ambiguum (R.H.Thompson) S. Carty \& Elenor R. Cox, a freshwater species from Kansas, USA, shares a small, diamond-shaped anterior intercalary plate with $H$. caspica, but differs in having only five precingular plates (Carty \& Cox 1986). The specimen called D. caspica by Lindemann (1927, p. 419-420) from the Caspian Sea with five precingular plates resembles Kansodinium ambiguum in its tabulation, but differs in its more rounded cell shape, smoother plate ornamentation, and different plate shapes; our specimens of $H$. caspica never showed five precingular plates. The phylogenetic relationship between Kansodinium and Huia will be the focus of future work.

Here we present the cyst-theca relationship of Huia caspica and thus added to the species diversity of diplopsalioideans with a cyst stage. The cyst morphology of $H$. caspica is superficially indistinguishable from the cysts of Niea chinensis, Diplopelta globula (Abé) Balech, Diplopsalis lenticula, Diplopsalopsis ovata (Abé) J.D. Dodge \& Toriumi, and Gotoius abei Matsuoka regarding the spherical shape and smooth 
surface. Furthermore, all of these species possess a theropylic archeopyle, although the suturing differs and there are differences in size and color (Matsuoka 1988; Liu et al. 2015). The cyst of Diplopsalopsis ovata has two flagellar scars and can be separated from the other species (Liu et al. 2015). So far, nearly half of the diplopsalioideans are known to produce cysts (Matsuoka 1988; Liu et al. 2015), in contrast to about 13-16\% of all living dinoflagellates (Head 1996). From an evolutionary view, the cyst stages may help the heterotrophic species to survive periods when food sources are scarce. Massive encystment was reported for Preperidinium meunierii (Pavillard) Elbrächter to retain the population and prevent washing out from the coastal environments (Joyce \& Pitcher 2004).

Our molecular phylogeny largely conforms to the previous report regarding the subdivisions of the diplopsalioideans into three clades (Liu et al. 2015). Huia caspica is phylogenetically distant from $D$. lenticula, consistent with the fact that they differ in the cell shape (spherical versus lenticular) and the shape of plate 1a (parallelogrammic versus narrow and five-sided). It is surprising that the closest relative of Huia is Lebouraia as they differ in the shape of the first apical plate (an ortho $1^{\prime}$ versus a meta $1^{\prime}$ ) and the number of anterior intercalary plates (one versus two). Either difference will justify their classification into various genera. The genera Oblea and Boreadinium share a meta 1' with Lebouraia, but differ in the number of anterior intercalary plates (Liu et al. 2015). They are not grouped together in the molecular phylogeny, supporting the systematic significance of the number and shape of anterior intercalary plates in this group of dinoflagellates. This is in contrast with 
the genus Protoperidinium, which incorporates species with one, two or three anterior intercalary plates, but remains a monophyletic group (Gu et al. 2015). The Diplopsalioideans might have experienced a rapid diversification during their evolution. Unfortunately, other molecular markers such as small subunit ribosomal (SSU) and internal transcribed spacer (ITS) are available only for a few species of the diplopsalioideans, thus molecular phylogeny study with concatenated data will be the focus of future work.

Species of the subfamily Diplopsalidoideae are predominantly marine (Abé 1941; Nie 1943; Abé 1981; Dodge \& Hermes 1981; Matsuoka 1988; Dodge \& Toriumi 1993), although many of them are able to inhabit brackish waters too, such as diplopsalioideans recorded in the Black Sea (Gómez \& Boicenco 2004). Some of them, e.g. Oblea rotunda (Lebour) Balech ex Sournia, can even tolerate salinities as low as 1.1 (Chomérat et al. 2004). The inland migration of marine dinoflagellates has been reported for the autotrophic species Scrippsiella trochoidea (Hameed \& Saburova 2015). The Diplopsalidoideae are exclusively heterotrophic and many of them (e.g. Diplopsalis, Oblea, Preperidinium) are generalists feeding on a variety of diatoms and other dinoflagellates (Strom \& Buskey 1993; Naustvoll 1998, 2000), thus it is not surprising that some of them have followed their prey and resided in waters with much lower salinity, as suggested for Oblea rotunda (Chomérat et al. 2004).

Only a few dinoflagellate species have succeeded in crossing the marine-freshwater boundary. So far, Kolkwitziella acuta and Huia caspica are known to be present in both brackish and fresh waters (Ostenfeld 1902; Mertens et al. 2015; 
Zhang et al. 2015). Other dinoflagellates known to inhabit both marine and fresh waters are limited to "Scrippsiella" hangoei and Durinskia baltica (K. M. Levander) S. Carty \& E. R. Cox (Imanian \& Keeling 2007; Annenkova et al. 2015). It is worth noting that all of them have a known cyst stage except $D$. baltica (Kremp \& Parrow 2006; Mertens et al. 2015), suggesting that cysts might be helpful to make the transition. To our knowledge, no species of other unicellular algae can inhabit both marine and fresh water ecosystems. The limited number of species that have crossed the marine-freshwater boundary suggest that it is difficult to make such a transition. The extant freshwater species might be the outcome of invasions long time ago and subsequent diversification, as marine and freshwater species usually do not group together in the molecular phylogeny (Logares et al. 2007b). The adaption to freshwater of a marine dinoflagellate might be accompanied by changes in genome structure and gene expression. This has occurred in the marine-freshwater evolutionof stickleback fish species flock (Jones et al. 2012).

The variation of those neutral molecular markers might not reflect the rapid diversification process (Orr \& Smith 1998), as demonstrated in "Scrippsiella" hangoei and "Peridinium" aciculiferum which have evolved into different morphospecies but retained identical ribosomal DNA sequences (Logares et al. 2007a). The brackish "S." hangoei differs from freshwater "S." hangoei at only one position in ITS region and the latter even shares identical ITS sequence with freshwater "Peridinium" baicalense and "P." euryceps, possibly due to rapid diversification of this species flock (Annenkova et al. 2015). Sharing of an identical 
LSU rDNA sequence between marine and freshwater Huia caspica suggest that its marine-freshwater transition might be a recent event. In fact, the artificial reservoir where H. caspica was recovered is connected to the Yellow River (Zhang et al. 2015), which was separated from the Bohai Sea until around 0.15 MaBP (Wang et al. 2001). A single species from different habitats can show pronounced variation in ribosomal DNA sequences, for instance, marine Durinskia baltica (AF231803) differs from its freshwater counterpart (GU999528) at 32 positions (98.33\% similarity) in SSU sequence. Durinskia baltica was classified within a diatom harbouring clade and most species within the clade inhabit fresh waters (You et al. 2015), suggesting that $D$. baltica might have re-colonized the marine waters.

\section{ACKNOWLEDGEMENTS}

We thank two anonymous reviewers for constructive suggestions that improved the ms. This project was supported by National Natural Science Foundation of China (41376170, 41306171).

\section{REFERENCES}

Abé, T. 1941. Studies on protozoan fauna of Shimoda Bay. The Diplopsalis group. Records Oceanography, Japan. 12: 121-44.

Abé, T. 1981. Studies on the family Peridiniales. An unfinished monograph of Armored Dinoflagellata. Publ. Seta Mar. Biol. Lab. Spec. Publ. Ser. 6: 1-409. Annenkova, N. V., Hansen, G., Moestrup, Ø. and Rengefors, K. 2015. Recent radiation in a marine and freshwater dinoflagellate species flock. ISME J. 9: 
$1821-34$

Batten, D. 1989. Cretaceous freshwater dinoflagellates. Cretaceous Res. 10: 271-3.

Bergh, R. S. and Daday, J. 1881. Der organismus der cilioflagellaten: Eine phylogenetische studie, W. Engelmann.

Boc, A., Diallo, A. B. and Makarenkov, V. 2012. T-REX: a web server for inferring, validating and visualizing phylogenetic trees and networks. Nucleic Acids Res. 40: W573-9.

Boltovskoy, A. 1975. Peridinium cinctum (Müller) Ehrenberg. Physis secc B. 34: 73-84.

Calado A.J. 2011. On the identity of the freshwater dinoflagellate Glenodinium edax, with a discussion on the genera Tyrannodinium and Katodinium, and the description of Opisthoaulax gen. nov. Phycologia 50: 641-9.

Carty, S. and Cox, E. R. 1986. Kansodinium gen. nov. and Durinskia gen. nov.: two genera of freshwater dinoflagellates (Pyrrhophyta). Phycologia. 25: 197-204.

Chomérat, N., Couté, A., Fayolle, S., Mascarell, G. and Cazaubon, A. 2004. Morphology and ecology of Oblea rotunda (Diplopsalidaceae, Dinophyceae) from a new habitat: a brackish and hypertrophic ecosystem, the Étang de Bolmon (South of France). Eur. J. Phycol. 39: 317-26.

Craveiro S.C., Moestrup Ø., Daugbjerg N. and Calado A.J. 2010. Ultrastructure and large subunit rDNA-based phylogeny of Sphaerodinium cracoviense, an unusual freshwater dinoflagellate with a novel type of eyespot. J. Eukaryot. Microbiol. 57: $568-85$. 
Dale, B., Montresor, M., Zingone, A. and Zonneveld, K. 1993. The cyst-motile stage relationships of the dinoflagellates Diplopelta symmetrica and Diplopsalopsis latipeltata. Eur. J. Phycol. 28: 129-37.

Daugbjerg, N., Hansen, G., Larsen, J. and Moestrup, Ø. 2000. Phylogeny of some of the major genera of dinoflagellates based on ultrastructure and partial LSU rDNA sequence data, including the erection of three new genera of unarmoured dinoflagellates. Phycologia 39: 302-17.

Dodge, J. D. and Hermes, H. 1981. A revision of the Diplopsalis group of dinoflagellates based on marterial from the British Isles. Bot. J. Linn. Soc. 83: $15-26$.

Dodge, J. D. and Toriumi, S. 1993. A taxonomic revision of the Diplopsalis group (Dinophyceae). Bot. Mar. 36: 137-47.

Ehrenberg, C.G. 1836. Zusätze zur Erkenntniss grosser organischer Ausbildung in den kleinsten thierischen Organismen. Abhandlungen der Königlichen Akademie der Wissenschaften zu Berlin 1835: 150-81.

Fensome, R., Macrae, R., Moldowan, J., Taylor, F. and Williams, G. 1996. The early Mesozoic radiation of dinoflagellates. Paleobiology 22: 329-38.

Fensome, R. A., Taylor, F. J. R., Norris, G., Sarjeant, W. A. S., Wharton, D. I. and Williams, G. L. 1993. A classification of fossil and living dinoflagellates. Micropaleontol. Spec. Publ. 7: 1-245.

Fritz, L. and Triemer, R. 1985. A rapid simple technique utilizing calcofluor white 
M2R for the visualization of dinoflagellate thecal plates. J. Phycol. 21: 662-4.

Gómez, F. and Boicenco, L. 2004. An annotated checklist of dinoflagellates in the Black Sea. Hydrobiologia 517: 43-59.

Gu, H., Liu T. and Mertens K. 2015. Cyst-theca relationship and phylogenetic positions of Protoperidinium (Peridiniales, Dinophyceae) species of the sections Conica and Tabulata, with description of Protoperidinium shanghaiense sp. nov. Phycologia 54: 49-66.

Guillard, R. R. L. and Ryther, J. H. 1962. Studies of marine planktonic diatoms. I. Cyclotella nana Hustedt and Detonula confervacea Cleve. Can. J. Microbiol. 8: 229-39.

Hall, T. A. 1999. BioEdit: a user-friendly biological sequence alignment editor and analysis program for Windows 95/98/NT. pp. 95-98.

Hameed H.A. and Saburova M. 2015. First record of Scrippsiella trochoidea (Dinophyceae) in Shatt Al-Arab River (Southern Iraq). Mar. Biodivers. Rec. 8: e150.

Head, M. 1996. Modern dinoflagellate cysts and their biological affinities. In Jansonius, J. and McGregor, D.C. (Eds) Palynology: principles and applications. American Association of Stratigraphic Palynologists Foundation, Dallas, pp. 1197-248.

Imanian, B. and Keeling, P. J. 2007. The dinoflagellates Durinskia baltica and Kryptoperidinium foliaceum retain functionally overlapping mitochondria from two evolutionarily distinct lineages. BMC Evol. Biol. 7: 172 . 
Jones, F. C., Grabherr, M. G., Chan, Y. F. et al. 2012. The genomic basis of adaptive evolution in threespine sticklebacks. Nature 484: 55-61.

Joyce L.B. and Pitcher G.C. 2004. Encystment of Zygabikodinium lenticulatum (Dinophyceae) during a summer bloom of dinoflagellates in the southern Benguela upwelling system. Estuar. Coast. Shelf Sci. 59: 1-11.

Katoh, K., Kuma, K., Toh, H. and Miyata, T. 2005. MAFFT version 5: improvement in accuracy of multiple sequence alignment. Nucleic Acids Res. 33: 511-8.

Kawami, H., Iwataki, M. and Matsuoka, K. 2006. A new diplopsalid species Oblea acanthocysta sp. nov. (Peridiniales, Dinophyceae). Plankton Benthos Res. 1: $183-90$.

Kremp A. \& Parrow M.W. 2006. Evidence for asexual resting cysts in the life cycle of the marine peridinoid dinoflagellate, Scrippsiella hangoei. J. Phycol. 42: 400-9.

Kretschmann, J., Elbrächter, M., Zinssmeister, C. et al. 2015. Taxonomic clarification of the dinophyte Peridinium acuminatum Ehrenb., $\equiv$ Scrippsiella acuminata, comb. nov. (Thoracosphaeraceae, Peridiniales). Phytotaxa 220: 239-56.

Lemmermann, E. 1910. Kryptogamenflora der Mark Brandenburg, III. Algen, I. Gebriider Born- traeger, Leipzig, Germany, Gebrüder Borntraeger.

Lewis, J. 1990. The cyst-theca relationship of Oblea rotunda (Diplopsalidaceae, Dinophyceae). Brit. Phycol. J. 25: 339-51.

Lindemann, E. 1927. Über einige Dinoflagellaten des Kaspischen Meeres. Archive für Protistenkünde 59: 417-22.

Liu, T., Mertens, K. and Gu, H. 2015. Cyst-theca relationship and phylogenetic 
positions of the diplopsalioideans (Peridiniales, Dinophyceae), with description of Niea and Qia gen. nov. Phycologia 54: 210-32.

Loeblich, A. R. 1980. Dinoflagellate nomenclature. Taxon 29: 321-8.

Logares, R., Rengefors, K., Kremp, A. et al. 2007a. Phenotypically different microalgal morphospecies with identical ribosomal RNA: a case of rapid adaptive evolution? Microb. Ecol. 53: 549-61.

Logares, R., Shalchian-Tabrizi, K., Boltovskoy, A. and Rengefors, K. $2007 b$. Extensive dinoflagellate phylogenies indicate infrequent marine-freshwater transitions. Mol. Phylogen. Evol. 45: 887-903.

Matsuoka, K. 1988. Cyst-theca relationships in the diplopsalid group (Peridiniales, Dinophyceae). Rev. Palaeobot. Palynol. 56: 95-122.

Mertens, K. N., Takano, Y., Yamaguchi, A. et al. 2015. The molecular characterization of the enigmatic dinoflagellate Kolkwitziella acuta reveals an affinity to the Excentrica section of the genus Protoperidinium. Syst. Biodivers. 13: $509-24$.

Nie, D. 1943. Dinoflagellata of the Hainan region VI. on the genus Diplopsalis. Sinensia 14: 1-21.

Naustvoll L.J. 1998. Growth and grazing by the thecate heterotrophic dinoflagellate Diplopsalis lenticula (Diplopsalidaceae, Dinophyceae). Phycologia 37: 1-9.

Naustvoll L.J. 2000. Prey size spectra and food preferences in thecate heterotrophic dinoflagellates. Phycologia 39: 187-98.

Orr, M. R. and Smith, T. B. 1998. Ecology and speciation. Trends Ecol. Evol. 13: 
$502-6$.

Ostenfeld C.H. 1902. Phytoplankton fra det Kaspiske Hav. Videnskabelige Meddelelser fra den naturhistoriske Forening I Kjubenhavn 1901: 129-39.

Ostenfeld C.H. 1908. The phytoplankton of the Aral Sea and its affluents, with an enumeration of the algae observed. Wiss Ergebnisse Aralsee Expedtion 8: 123-225.

Posada, D. 2008. jModelTest: phylogenetic model averaging. Mol. Biol. Evol. 25: $1253-6$.

Ronquist, F. and Huelsenbeck, J. P. 2003. MrBayes 3: Bayesian phylogenetic inference under mixed models. Bioinformatics 19: 1572-4.

Schiller, J. 1935. Dinoflagellatae (Peridineae) in monographischer Behandlung. In Kolkwitz R.(Ed) Rabenhorst's Kryptogamen-flora von Deutschland, Österreich und der Schweiz, 2nd ed., 10 (3). Part 2, Issue 1, Akademische Verlagsgesellschaft, Leipzig, pp. 1-160.

Scholin, C. A., Herzog, M., Sogin, M. and Anderson, D. M. 1994. Identification of group- and strain-specific genetic markers for globally distributed Alexandrium (Dinophyceae). II. Sequence analysis of a fragment of the LSU rRNA gene. $J$. Phycol. 30: 999-1011.

Stamatakis, A. 2006. RAxML-VI-HPC: maximum likelihood-based phylogenetic analyses with thousands of taxa and mixed models. Bioinformatics 22: 2688-90.

Strom S.L. and Buskey E.J. 1993. Feeding, growth, and behavior of the thecate heterotrophic dinoflagellate Oblea rotunda. Limnol. Oceanogr. 38: 965-77.

Taylor, F. J. R., Hoppenrath, M. and Saldarriaga, J. F. 2008. Dinoflagellate diversity 
and distribution. Biodivers. Conserv. 17: 407-18.Wang, S., Wu, X., Zhang, Z., Jiang, F., Xue, B., Tong, G. and Tian, G. 2001. Study on the environmental changes of three gates ancient lake in the sedimentary records and the Yellow River linking the sea. Sci China Earth 31: 760-8 (in Chinese).

Wołoszyńska, J. 1917. Neue Peridineen-Arten nebst Bemerkungen über den Bau der Hülle bei Gymno-und Glenodinium. Bulletin International de l'Academie des Sciences de Cracovie, Classe des Sciences Mathématiques et Naturelles, série B: Sciences Naturelles 1917: 114-22

You, X., Luo, Z., Su, Y., Gu, L. and Gu, H. 2015. Peridiniopsis jiulongensis, a new freshwater dinoflagellate with a diatom endosymbiont from China. Nova Hedwigia 101: $313-26$.

Zhang, Q., Song, H. Y., Hu, Z. Y. and Liu, G. X. 2015. Morphological examination and phylogenetic position of the newly recorded heterotrophic brackish dinoflagellate Diplopsalis caspica (Dinophyceae) in freshwater habitat from China. J. Syst. Evol. 53: $512-9$.

\section{FIGURE CAPTIONS}

Figs 1-7. LM of live (Fig. 1) and calcoflour stained (Figs 2-7) vegetative cells of Huia caspica.

1. Cell showing pale green granules. 
2. Cell in ventral view, showing the first apical plates $\left(1^{\prime}\right)$, an anterior sulcal plate $(\mathrm{Sa})$, a left sulcal plate $(\mathrm{Ss})$ and a right sulcal plate $(\mathrm{Sd})$.

3. Cell in apical view, showing a round pore plate $(\mathrm{Po})$ and a short canal plate $(\mathrm{X})$.

4. Cell in ventral view, showing the first apical plates $\left(1^{\prime}\right)$.

5. Cell in apical view, showing three apical plates $\left(1^{\prime}-3^{\prime}\right)$, six precingular plates $\left(1^{\prime \prime}-6^{\prime \prime}\right)$ and one anterior intercalary plate (1a).

6. Cell in ventral view showing three cingular plates $(1 \mathrm{c}-3 \mathrm{c})$, the transitional plate $(\mathrm{t})$.

7. Cell in antapical view showing five postcingular plates $\left(1^{\prime \prime \prime}-5^{\prime \prime \prime}\right)$, one antapical plate (1"'"') and a posterior sulcal plate (Sp). 

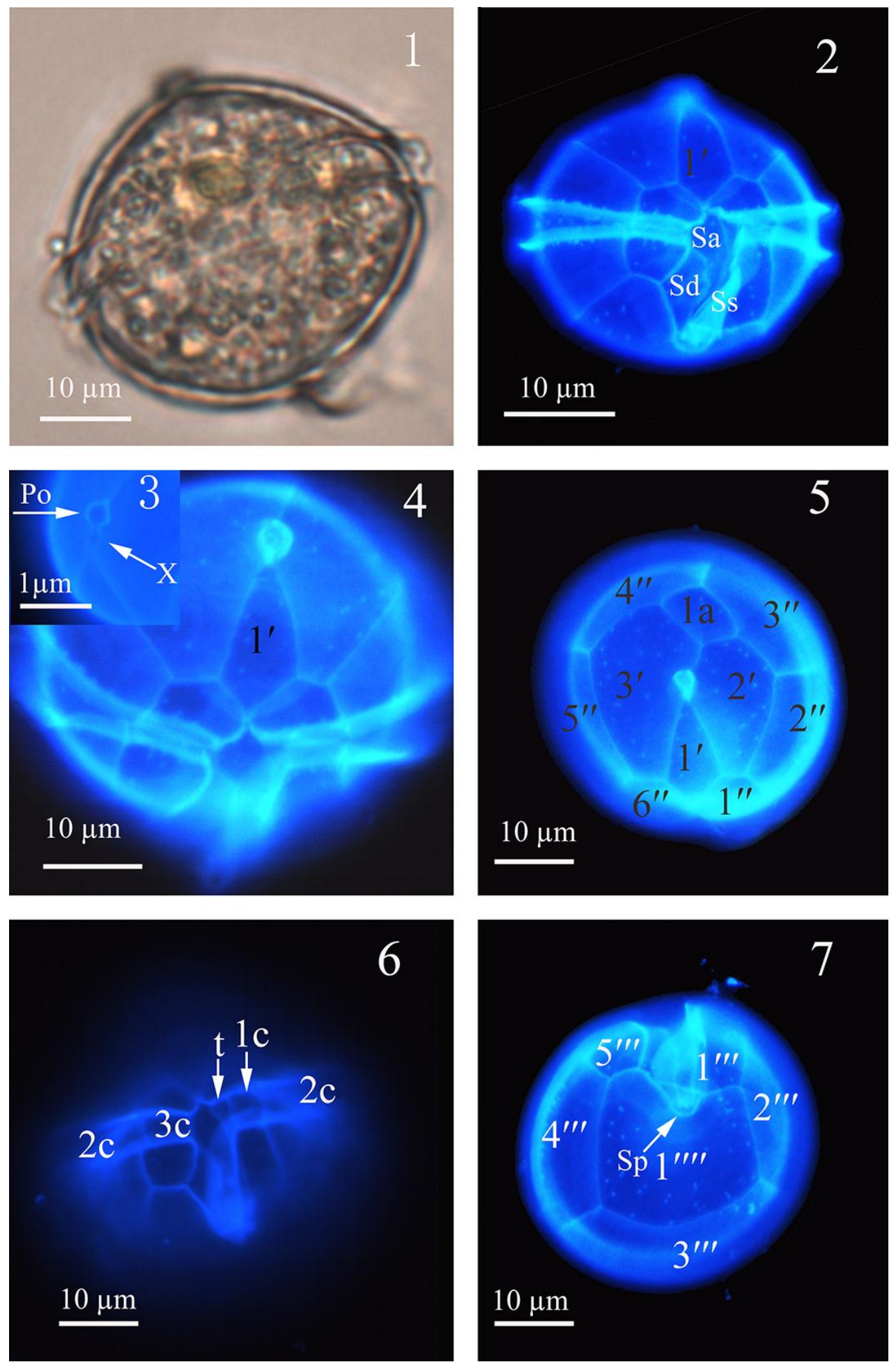
Figs 8-11. LM of cysts of Huia caspica.

8. A living cyst showing the thick walls and full of granules.

9. An empty cyst showing the smooth wall.

10, 11. Empty cysts showing the theropylic archeopyle (arrows).
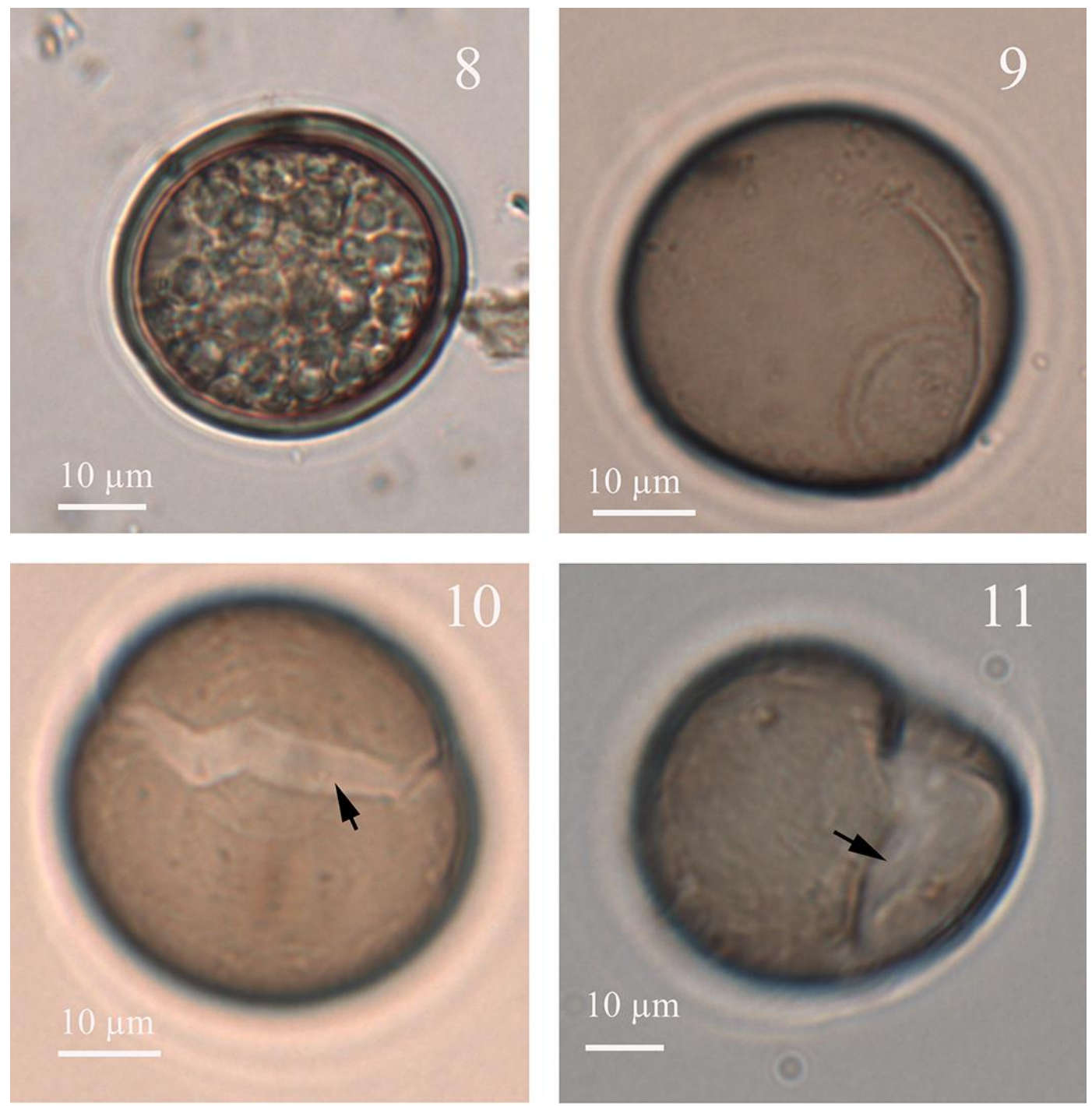
Fig. 12. Drawing of the archeopyle. The anterior intercalary plate is shaded, and the archeopyle sutures are indicated with heavy black lines.

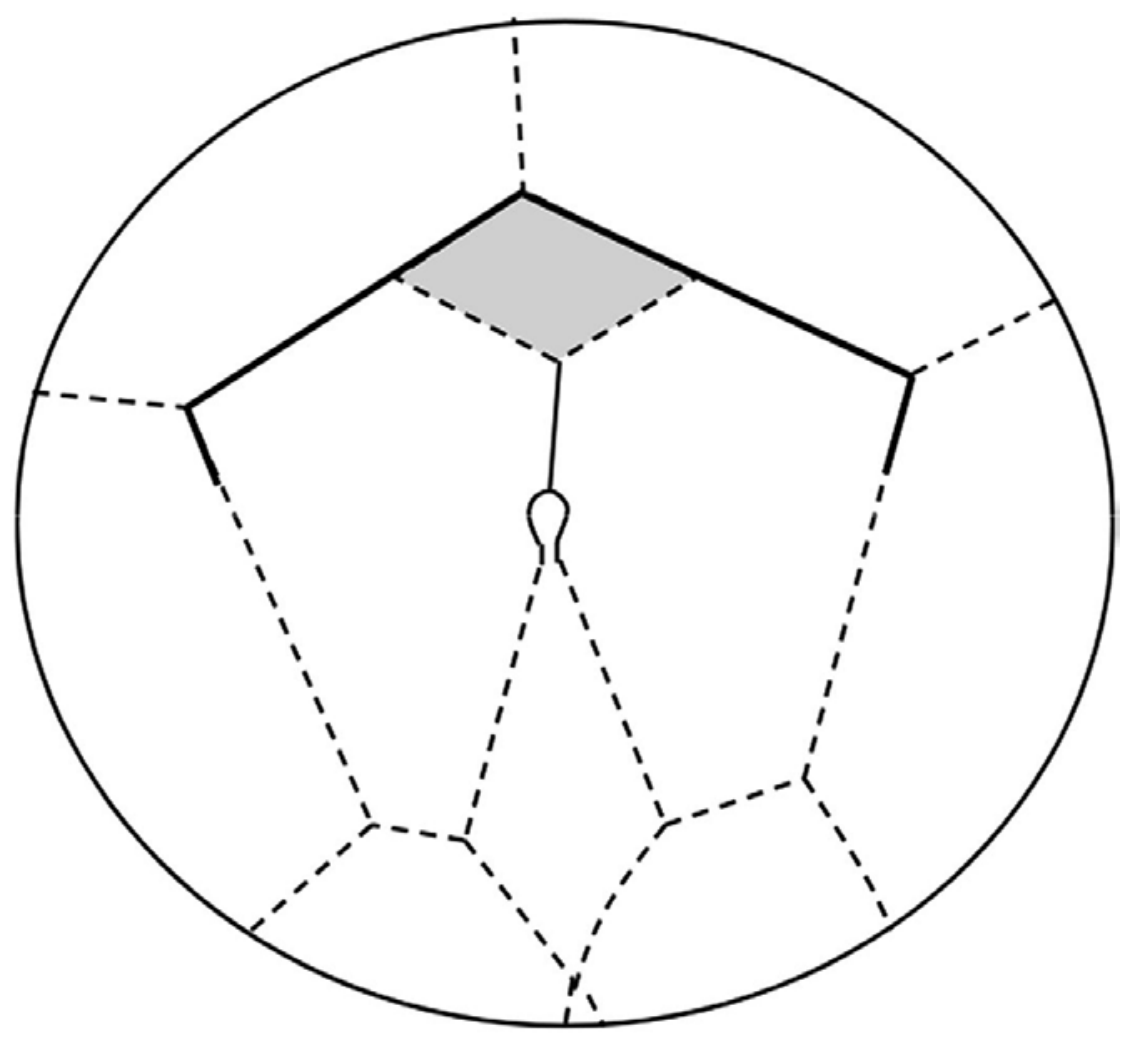

Fig. 13. A phylogenetic tree of the diplopsalioideans inferred from partial large subunit ribosomal DNA sequences using Bayesian inference (BI). The apicomplexan Neospora caninum was selected as an outgroup. The scale bar indicates the number of the substitutions per site. Bootstrap value ( $>50 \%)$ for maximum likelihood (ML) / Posterior probability $(>0.9)$ for BI support are shown. * indicates maximal support (ML bootstrap support=100 / BI posterior probability=1.00). Dashed lines indicate a half length. Clades are labeled and marked with vertical lines on the right. Sequences obtained in this study are indicated in bold. 


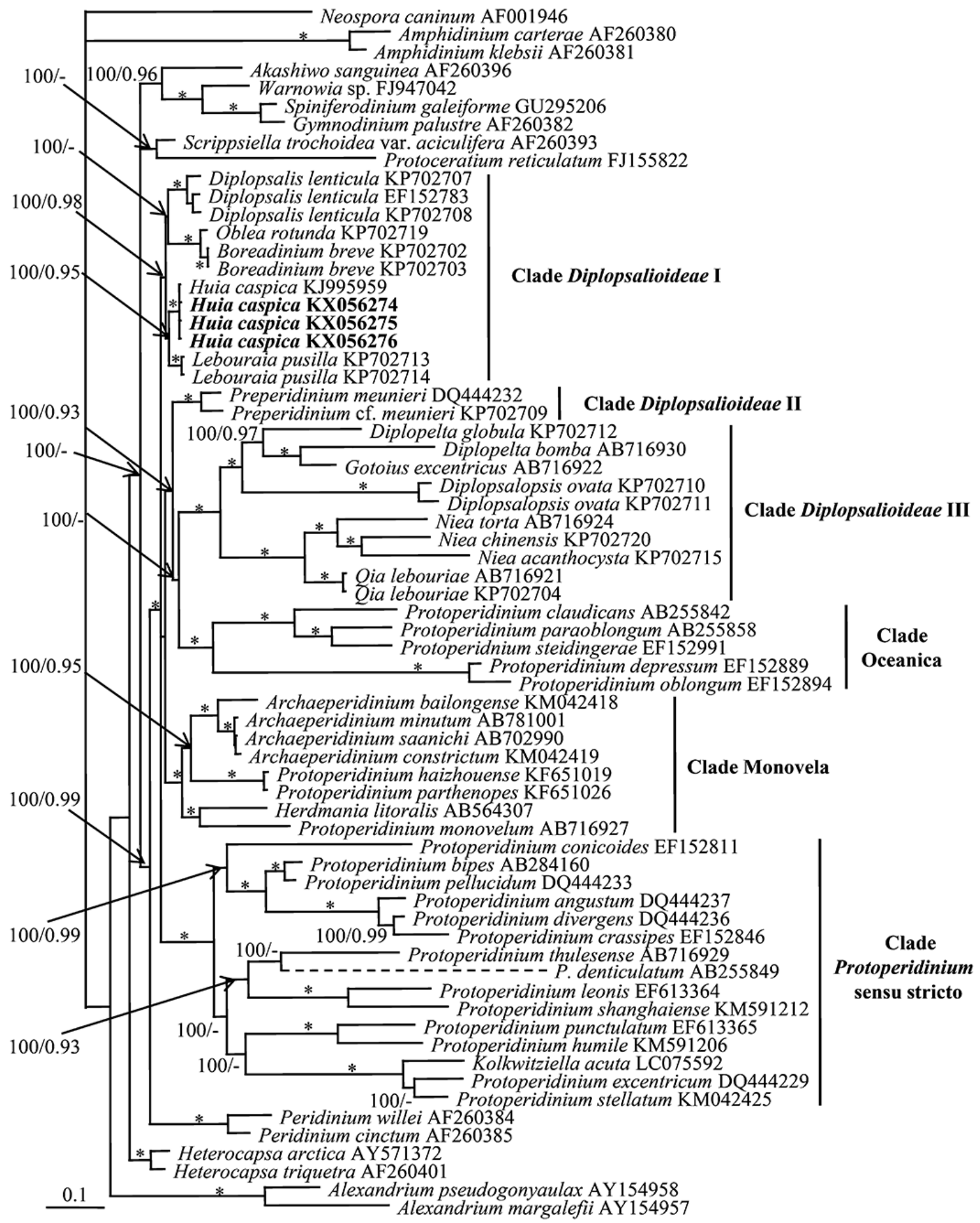


Fig. S1 Map showing the distribution of Huia caspica: cysts (this study, shown in red circle), motile cells in plankton samples (literature, shown in blue circle).

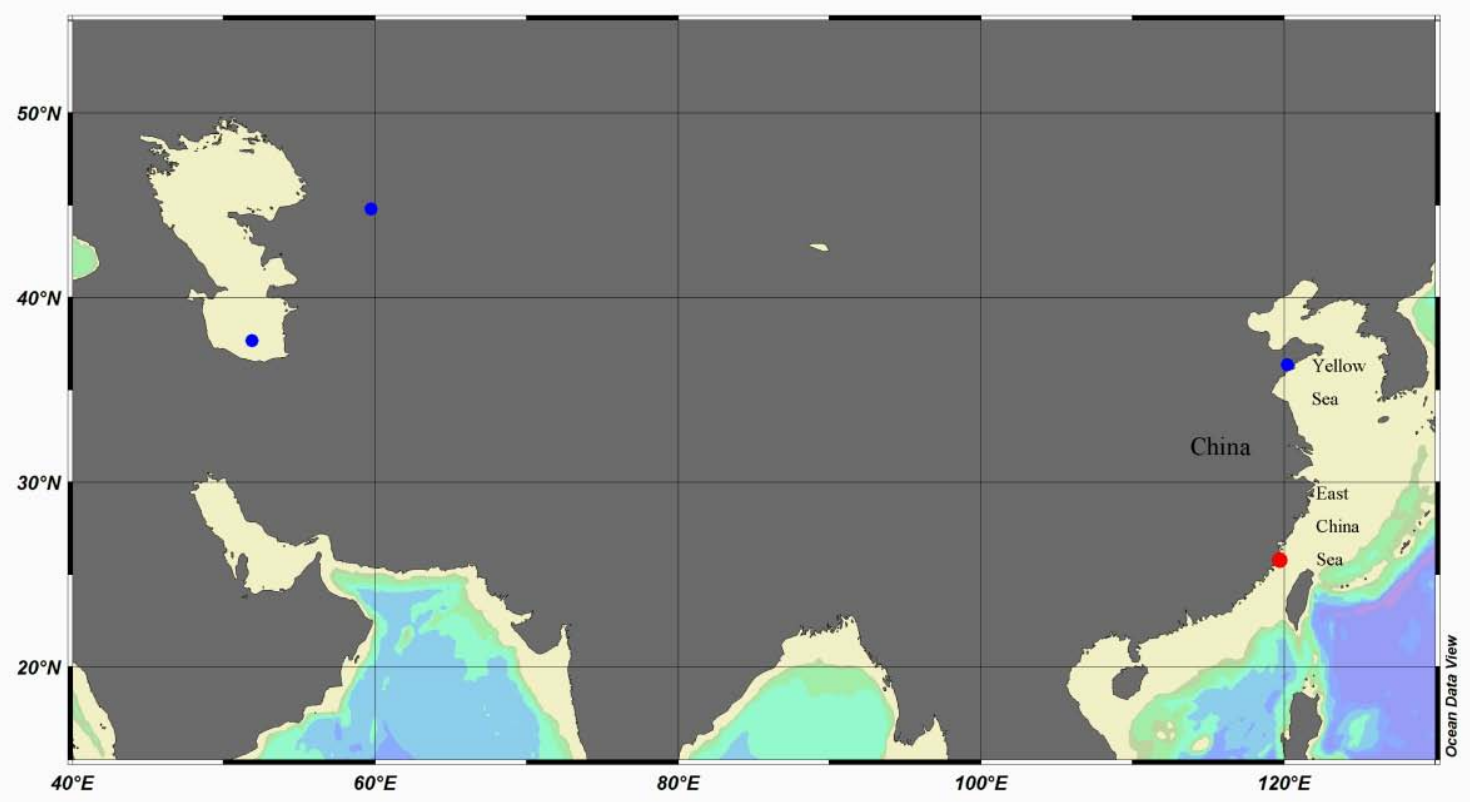

